\title{
Tendency and Dynamics of Communicative-Speech Development of a Preschool Age Child
}

\section{Тенденції та динаміка комунікативно-мовленнєвого розвитку дитини дошкільного віку}

\author{
Tamara Pirozhenko ${ }^{1}$ \\ Dr. in Psychology, \\ Professor

\section{Iryna Soroka ${ }^{2}$} \\ Ph.D. in Psychology, \\ Assistant Professor \\ ${ }^{1}$ G.S. Kostiuk Institute of Psychology \\ of the National Academy of \\ Educational Sciences of Ukraine \\ $\triangle 2$, Pankivska Str., Kyiv, \\ Ukraine, 01033 \\ ${ }^{2}$ «Law Institute «KNEU named \\ after Vadym Hetman» \\ $\triangle$ 81, Melnikova Str., Kyiv, \\ Ukraine, 03057
}

Тамара Піроженко ${ }^{1}$

доктор психологічних наук, професор

E-mail: 5197536tp@gmail.com orcid.org/0000-0001-9822-4819

Ірина Сорока

кандидат психологічних наук, доцент

E-mail: ira.sor@ukr.net

orcid.org/0000-0003-1132-488X

${ }^{1}$ Інститут психологіі

імені Г.С. Костюка НАПН Украӥни

$\triangle$ вул. Панківська, 2, м. Київ, Україна, 01033

${ }^{2}$ «Юридичний інститут «КНЕУ імені Вадима Гетьмана»

$\triangle$ вул. Мельникова, 81, м. Київ, Україна, 03057

Original manuscript received April 15, 2018 Revised manuscript accepted October 25, 2018

\section{ABSTRACT}

The article presents the characteristic of communicative-speech development of a child in the unity of behavioural, cognitive, and creative qualities of 
speech. An integrated approach to assessing the state of personality activity and the child's self-realization through the genesis of speech has been implemented. Criterion estimations, diagnostic examination of the level of speech development of the child from the position of the communicative direction, the authors method of examination in the unity of emotionalvolitional, cognitive, and creative qualities of speech are presented in this work. The basic foundations of the communicative-speech development of the child in the interrelation of the components of the characteristics of the conative, cognitive-linguistic, personal levels are analyzed, the age peculiarities in the development of competence of the child in the sphere of speech communication are generalized. Conative achievements of the junior preschool child provide the formation of such personality traits as a communicative orientation to the surrounding world, openness to the experience of adults and peers, which lead to an increase in the cognitive complexity of speech behaviour of children of middle preschool age. The cognitive-linguistic level of the child's achievements is associated with the assimilation of the relations between "man-situation» and the relations "linguistic form-significance». The language becomes the object of manipulation and awareness. The formation of various forms of speech expressions, adequate to the situation and partner environment, provides the child with the realization of the needs of communication, the further development and complexity of cognitive forms of interaction, the development of ways and processes of thinking and creativity in speech communication.

Key words: communicative-speech development, conative, cognitive, linguistic and personal qualities of speech, language competence.

\section{Introduction}

Different approaches to understanding children's language, speech and communication exist in the scientific literature. Many concepts of language interactions are based on Piaget's (1959) theory of cognitive and language development and Vygotsky's (1986) socio-cultural theory. Vygotsky, who repeated some of Piaget's experiments, insisted that the earliest speech of the child is already social. At a certain age, this original social speech becomes rather sharply divided into egocentric speech, that is, speech-for-oneself, and communicative speech-for-others (Vygotsky, 1986).

N. Chomsky (2002) to explain how a child so rapidly and effortlessly acquires its natal language concluded that he comes into the world with the essentials of grammar already pre-installed. The scientist described a language as a mirror of the mind. Language is a 
natural object, a component of the human mind, physically represented in the brain (Chomsky, 2002: 161). Sociology of childhood recognizes the complex language interactions in which children engage with each other and with adults. While developmental approach focuses attention on individual children's own learning and socialization from a cognitive perspective, the sociological approach describes children, through their talk and interaction, as actively constructing their own social situations. Gestures, movements, laughter, and even silence are considered important features in understanding how children make sense of their play (Danby, 2002).

M. Tomasello (2008) agrees with an approach that emphasiges the need for cooperative prerequisites for the origin of human communication. If we are to understand the ultimate origins of human communication, both phylogenetically and ontogenetically, we must look outside of communication itself and into human cooperation more generally. It turns out that human cooperation is unique in many ways, both structurally and motivationally (Tomasello, 2008; Hurford, 2007).

N. Kharchenko analyzed the problem of ontogenesis of the language personality of a preschool child in the context of listening development (Kharchenko, 2017: 174). L. Kalmykova and G. Novikova stated that language competence of a child is generally formed before the age of five. These researchers also described some strategies and tactics for the empirical acquisition by preschoolers of language knowledge, in particular: imitation, constructing, unconscious language generalizations, attempts and mistakes, word formation, adaptation to the conditions of speech communication (Kalmykova \& Novikova, 2018: 100).

Learning the basic characteristics of communicative language development requires the analysis of qualities of mental development of the individual (Hermer-Vazquez et al., 2001), which help the child establish interpersonal contact, perform socially perceptive analysis of the system «man - situation», choose the appropriate nonverbal and verbal means of communication, monitor the success of purposes of communication, be creative. A complex approach to assessing speech as integrated characteristics of personal development needs to include methods for studying the creative possibilities of speech texts, analysis of a child's personal self-expectations, values orientation, reflecting human relations that mediate the activity of the child and allow him to act independently on behalf of his own «I», and methods for monitoring 
the expression of personality traits, providing successful mutual understanding (Maksimenko, 2000).

Justification criterion assessments, indicators and survey methods of communicative and language development of preschool children, reflecting the studied phenomenon (child's speech) as an important personal characteristics allowed to perform the task of the analysis of its basic foundations and the construction of the characteristics into the integrated structure (Pirozhenko, 2002, 2010). Presented further materials describe the basic characteristics and the degrees of conative, cognitive, linguistic and personal characteristics that provide the subjective level of regulating the speech.

\section{Participants}

The analysis of the trends of the described phenomenon was conducted on a sample of 538 children of senior preschool and primary school age. These are children of preschool educational institutions from Kyiv (No 281, 491, 444, 613, 580, 409), Zhytomyr (No 53, 52, 69); pupils of 1-2 classes of secondary school No 29 and No 50 of Zhytomyr; Korosten (No 17; 12; 84; 2); from Mykolayiv ( $2^{\text {nd }}$ grade pupils of school No 86 and $3^{\text {rd }}$ grade of secondary school No 50). All these educational institutions are typical of the pre-school and primary education system. The work aimed at the development of verbal communication and improving of emotional and volitional, cognitive, linguistic features of speech was conducted with the children from the experimental groups.

\section{Research methods}

The following methods were used in this research: theoretical and methodological analysis and generalization of the problem, a projection of psychological and pedagogical interaction of the educator with children, experimental-genetic method. To determine the psychological characteristics of the integral structure of communicative-speech ontogeny in different age periods of childhood the method developed by the author to examine the qualities necessary for speech communication was used. Such documentary sources of productive activity of children as an analysis of drawings, thematic albums, home-made children books; as well as questionnaires and expert evaluations of adults for the 
Tendency and Dynamics of Communicative-Speech Development...

non-verbal behaviour of children, observation of communication between children and adults, and projective methods were used in this research.

\section{Results and Discussion}

The empirical model of communicative-speech development, created by the authors, is introduced in Table 1 below.

Table 1. Empirical model of communicative-speech development

\begin{tabular}{|c|c|}
\hline & Empirical model of communicative-speech development \\
\hline $\begin{array}{l}\text { Conative level } \\
\text { (behaviour) }\end{array}$ & $\begin{array}{l}\text { Communicative features: } \\
\text { a) focus on the partner, setting on the appropriate reaction; } \\
\text { b) variety of expressive-mimic means of communication; } \\
\text { c) availability of contact-setting tools for interaction. }\end{array}$ \\
\hline $\begin{array}{l}\text { Cognitive- } \\
\text { linguistic level }\end{array}$ & $\begin{array}{l}\text { A. Cognitive speech features: } \\
\text { a) understanding of the spatial-temporal characteristics of the } \\
\text { communicative situation; } \\
\text { b) emotional content of the situation of communication (consciousness). } \\
\text { B. Linguistic speech features: } \\
\text { a) rich vocabulary; } \\
\text { b) grammatical correctness; } \\
\text { c) phonetic features of speech. }\end{array}$ \\
\hline Personal level & $\begin{array}{l}\text { A. Arbitrary speech: } \\
\text { a) coherence, cohesiveness of the text; } \\
\text { b) the nature of the text; } \\
\text { c) elevance of the speech to the purpose of interaction. } \\
\text { B. Personal qualities: } \\
\text { a) self-esteem, friendliness, sociability, etc. } \\
\text { b) value orientations; } \\
\text { c) motives of communication. }\end{array}$ \\
\hline
\end{tabular}

The analysis of the data, received during our research, indicates that the children with high levels of communicative-speech development show the great representation of conative, cognitive, linguistic and personal achievements, ensuring the success of language interaction and rapport with people. The level of development of dialogical qualities of verbal behaviour, cognitive competence in assessing a situation and partner surrounding, personal achievements, expressed in developed motives of communication, the ability to regulate and exercise creativity in language interactions - all of these ultimately provide the child with the successful interaction in the social environment. The degree of combination of different psychological qualities of a child in the 
process of speech interaction demonstrates personal experience of relationship with people.

The development of the basic foundations of a conative level of communicative speech development of children of preschool and primary school age clearly indicates their importance and significant contribution to the further development of qualities that are expressed in the development of cognitive, linguistic and personal achievements. The dynamics of the relationship of such communication qualities of behaviour as the setting of certain reaction, readiness for cooperation, dialogic speech communication indicate their priority in the development of speech. By all accounts of cognitive-linguistic and personal levels, communication qualities have a positive correlation and the degree of their formation ensures the development of communication, cooperation, openness to the experience of others and the development of learning abilities. Ignoring given character of relationships leads to the fact that in teaching practice of preschool education the problems of non-verbal behaviour rupture from the leading signs. That is, being able to express different emotional states and roles the child is not able to assess emotional states and worries of a real partner. This gap violates logic and consistent pattern of development of communicative speech achievements. For the period of childhood this is a dangerous trend, as it further causes the formation of an insincere formal behaviour, neglection of a personal attitude to the participants of a contact, the lack of emotional components in dialogical interaction and violation of the foundations of their own individual style of speech behaviour in communicating with people.

Cognitive-linguistic level of communicative speech development of the child is reflected in the ability to analyze and synthesize, to select major and minor in assessing the situation of communication and partnership environment, to decide on further communication purpose (persuade, negotiate, agree), shows the development of practical and common sense, based on personal experience, emotions, intuition and imagination. The cognitive block of achievements in speech communication provides the further opportunity of creative interpretation of the situation, the development of general ability to language creativity, indicates the assimilation by a child not only the expressive and nominative function of speech, but also the development of prognostic function. 
The study of cognitive-linguistic signs of preschool child's speech made it possible to identify qualitative features and certain levels of development. Harmonious correlation of cognitive and linguistic character is distinctive for a high level of a communicative speech development of children. The child demonstrates the choice of adequate and reasonable language tools, uses a variety of grammatical constructs to assert his opinion, phonetically correct and in accordance with communication problems formulates his speech, indicating prospects and great potential for further development.

A medium level of an integrated communicative speech development of children demonstrates the reduction of a balance between cognitive and linguistic qualities of speech. There is an imbalance of cognitive and linguistic activity. The lack of cognitive assessment of situational and participatory environment, inaccurate or incorrect assessment of verbal communication attributes causes the need to improve a child's linguistic activity. Too much speech does not reach the target of communication - mutual understanding. The harmonious combination of cognitive and linguistic components contribute to the overall focus on self-expression of an opinion, expressed in the speech utterance, which is ensured by the emergence of arbitrary qualities of verbal behaviour. The medium level of cognitive-linguistic achievements of the child can be seen as a signal for the teacher as for the breach of the harmony in the development of the necessary components of speech. The medium level of cognitive and linguistic features of a child's speech is expressed both in a general decrease in speech activity and in increased chatter which is far from the conscious interaction. Discovered imbalance and the breach of the harmony of cognitive and linguistic features are more notable in children with low levels of speech, in which the proportion of cognitive skills exceeds the linguistic by two times. It is noted that the low level of language means is accompanied by a cognitive retard. The child demonstrates minimization of the activity by restricting partner and situational interaction, reducing grammatical constructs and phonetically unintelligible speech. Impersonality, lack of own opinion and «authorship» in speech are accompanied by the uselessness of arbitrary regulation of verbal behaviour that hinders the development of subjective, personal level of activity in the speech communication (motives and values associated with relationships between people). A child with the low level of cognitive-linguistic achievements cannot 
show flexibility, a speed of decision making, perseverance, the coherence of speech expression and elements of creativity in communication, he demonstrates only adaptive activity.

The analysis of basic foundations of a personal level of communicative speech development in the holistic phenomenon reveals patterns that are associated with the characteristics of conative, linguistic and cognitive levels. Children with low levels of creative qualities and arbitrary regulation of speech point the problem in communication and language learning. In traditional methods of linguistics, such important characteristics of speech as coherence, cohesiveness, creativity remain neglected by the teacher. To develop the expected qualities of creativity, occurring in communicative speech activity, the atmosphere of cooperation, mutual understanding and support are needed.

The results of our experiment showed disturbing tendencies of the creative achievements characteristics:

Table 2. Levels of the creative achievements of senior preschool children

\begin{tabular}{cccc}
\hline Levels & Experimental group, \% & Control group, \% & General percentage, $\%$ \\
\hline High & 43 & 16 & 28 \\
Medium & 53 & 39 & 45 \\
Low & 4 & 45 & 27 \\
\hline
\end{tabular}

The level of development of creative speech has a close relationship with advances in behavioural (conative) character. Correlation of close variants of high-medium and high-low levels have opposite poles. This pattern reflects the characteristics of the imagination as procedural foundations of mental work. It is known that any action (including communication and speech) can be viewed at reproductive and creative levels. The children from the experimental groups practice verbal communication which develops imagination, involves creating a new situation, and a new imaginary «I» as the subject of this situation, the possibility of going beyond the real «I». Developed imagination, which is represented by a creative level of language, allows the child to take the position of the other, to be different and use reflective capabilities. Developed sphere of emotions, empathy, as the mechanism of understanding the partner, remains in the focus of adults' attention in teaching children speech communication, which develops the imagination as well. 
All options of qualities of the conative block having low values correlate negatively with the values of «creative speech». Options such as middle-high and high-low levels are impossible. A negative correlation has also had such variant as high (conative qualities) - low (speech creativity). High achievements of conative unit demonstrate the diversity, variety of ways of nonverbal nature and adequacy of situational and partner surrounding, which indicates a creative approach to the choice of means of communication. In this regard, it is important to emphasize that the preschool period of childhood is sensitive for development of creativity of the child's speech. Relying on natural age progression of creative elements in speech is impossible, which is confirmed by our data as for the trends of reduction of verbal creativity elements among primary school children compared to preschoolers. Communication activity aims to harmonize interpretations and establish rapport, but also eliminates unnecessary anxiety, by providing the child with emotional well-being in case of divergence of opinions and assessments. The atmosphere of support and confidence in mutual understanding is a necessary and psychologically favorable background that allows the child to reveal independence, a tendency to self-affirmation and creativity. In addition, the proposed method of analyzing situations develops among children of experimental groups such qualities of thinking as productivity (number of ideas), flexibility (the diversity of ideas, the ability to move from one situation to another), originality (the ability to generate ideas). All these qualities are seen as leading indicators of psychometric methods in assessing creativity as the ability.

The method of diagnosis and correction was used with the children of the experimental group. It is based on the discussion of the main content of the situation «What's happening?» and the search for evidence by updating the personal sensory experience «What makes you think so?» This approach makes the child reflect and express creativity in solving problems. Generating creative ideas by children has a positive correlation with the overall atmosphere of trust, openness, emotional well-being as well as the ability of the child to experience emotionally similar situations in life. The nature of the correlation of the conative signs of speech and the level of development of such psychological phenomena as self-esteem, communication and motivation latitude values, reflecting the interpersonal relationship, allow us to specify that 
all children are experiencing an acute need for identification with the image of «a good boy» or «a good girl».

Methods of assigning characteristics were developed by S. Tyschenko (Tyschenko, 1992). Most children from the experimental groups chose «definitely positive» characteristics. Children in the process of assigning characteristics easily overcome «logical barrier» between each postulated quality and negative manifestations denying this quality. Self-actualization of a child in such cases goes toward constructing «definitely positive» harmonious image of «I». In the control groups ratio selection of definitely «positive» features and characteristics of the negative additions look differently, «positive» characteristics were chosen by only the part (36.4\%) of children, «negative» characteristics were considered «theirs» by $29.9 \%$ of children and $33.7 \%$ not only failed to adapt characteristics while minimizing their negative aspects, but generally tried not to make a decision on the appropriation of any characteristics. Based on interviews with children, as well as by monitoring their emotional expressions in communication, it must be mentioned that their image of «I» has a strong affective colouring. Tension in the area of the «I $\rangle$ is caused by the collision of two opposing trends: the need to identify yourself with positive images and emotions associated with a negative experience of communicating with peers and relatives in a family environment. It is believed that self-assessment and peer evaluation in the experimental groups of children is more complex, differentiated, flexible, filled with situational meaning and justification of motives. The favorable conditions and experience of constructive interaction and interpersonal understanding remove excessive concern about their experiences of relationships with peers. Analyzing appropriation of the characteristics by the children it should be noted that the contradictory and mutually exclusive in terms of logic evaluations are unrelated to cognitive difficulties and a child's inability to properly understand and evaluate the proposed judgments. This is caused by the collision of the need for a positive self-identity and feelings, reflecting the negative experience of interaction. The risk of this condition in the overall assessment of the prospects of development of the child emphasizes the importance of self-awareness as an essential structural unit in personal development. The uniqueness of each person is a guarantee of a creative potential. A person ceases 
to exist as an individual if his or her identity defines only the social control. A similar effect of socialization takes place when a person from childhood is imposed by templates of estimation, when a person does not have a certain degree of freedom to develop and display personal attitude to himself. It should be noted that statistically significant variant among the children of the control groups is an option «low level of conative qualities» and «high option of a positive selection of value orientation» («good and evil»). This observation of a child's interaction with others and negative assessments regarding the theme «family» and «friends» indicate trouble. It is the manifestations of faith in the goodness of the child's surrounding people, despite his or her negative practical experience of communication (the facts of «genetic altruism») (Fromm, 1992).

Summarizing the analysis of the basic foundations and structural components in the development of a holistic phenomenon characterizing speech at conative, cognitive-linguistic, personal levels, the communication-speech characteristic can be recognized as the most important contribution to the development of verbal behaviour, consciousness, personality as a whole. The analysis of the basic foundations of these characteristics indicates the interconnection of mental qualities of each level. At the same time the higher (personal) level of achievements cannot be inferred from the prior level. The achievements of each level are the product of the activity of the child in communication with the environment, leading to the development of the necessary skills in interaction and synthesis into a coherent structured field. The activity allows the child to characterize the speech as a mental organization, as a new structuring of the psyche, which gain a new level of special status, role and place in such the phenomenon as an individuality of a child.

Critical thinking, creative thinking, communicating, and collaborating are the 21 st century learning skills (Soroka, 2017). As seen from this research, they have to be paid attention to and developed from the early childhood. Later on in life these skills help students learn and they are important to succeed at university. Students who develop these skills are more able to get better marks, become less dependent on teachers and textbooks. These learning skills are vital in future working life as well. 


\section{Conclusions}

Summarizing the materials of the study of communicative and speech development, we can formulate the following conceptual issues:

1. Ontogeny of communicative and speech development of a child of preschool age is a multi-level system of signs of the child's mental maturity as a subject of communication and it manifests itself on the behavioural (conative), cognitive-linguistic and personal levels. The degree of development of the levels of this sphere of the psyche reflects the dynamics of the child's relationship with the social environment, which mediates the activity of the child as a communication partner.

2. The study of communicative and speech development in the interrelation of the qualities of different levels made it possible to reveal their qualitative originality in different periods of childhood (junior, middle, senior preschool age).

3. Comparative analysis of the mental maturity of preschool children in experimental and control groups suggests that the evolvement of basic communicative and speech qualities in different age periods, lays the foundation for truly harmonious development of the personality, as it reveals the potential abilities of the child.

\section{References}

Chomsky, N. (2002). On Nature and Language (pp. 45-60). Cambridge : Cambridge University Press. doi.org/10.1017/CBO9780511613876

Danby, Susan J. (2002). The communicative competence of young children. Australian Journal of Early Childhood, 27(3), 25-30. http://www.earlychildhoodaustralia. org.a...

Fromm, E. (1992). Chelovek dlya sebya. Issledovanie psixologicheskix problem etiki [A man for himself. Research of psychological problems of ethics]. Minsk : «Kollegium» [in Russian].

Hermer-Vazquez, L., Moffet, A., \& Munkholm, P. (2001). Language, space, and the development of cognitive flexibility in humans: The case of two spatial memory tasks. Cognition, 79, 263-299. PMID: 11165214

Hurford, J.R. (2007). The Origins of Meaning. Language in the light of evolution. Oxford: Oxford University Press.

Kalmykova, L., \& Novikova, G. (2018). Psyxolingvistychni fenomeny «znannya movy» i «znannya pro movu»: problemy spivvidnoshennya $\mathrm{j}$ funkcionuvannya v movlenni ditej [Psychologistic Phenomena «Knowledge of the Language» and «Knowledge About Language»: Problems of Relationship and Functioning In Children's Speech]. Psyxolingvistyka - Psycholinguistics, 23(1), 99-118. DOI 10.5281/zenodo.1211606

Kharchenko, N. (2017). Movna osobystist doshkilnyka: osoblyvosti rozvytku v procesi audiyuvannya [Language personality of a preschool child: features of 
Tendency and Dynamics of Communicative-Speech Development...

development in the process of listening]. Psyxolingvistyka - Psycholinguistics, 21(1), 171-185. doi.org/10.5281/zenodo.1088464

Language Evolution and Human Development. Brian MacWhinney Carnegie Mellon University (2005). In D. Bjorklund \& A. Pellegrini (Eds.) Origins of the Social Mind: Evolutionary Psychology and Child Development (pp. 383-410). New York : Guilford Press. Retrieved from: http://www.inf.ed.ac.uk/teaching/courses/ cnl/MacWhinney_05.pdf

Maksimenko, S.D. (2000). Geneticheskaya psixologiya. Metodologicheskaya refleksiya problem razvitiya $v$ psixologii [Genetic psychology. Methodogical reflection of problems of development in psychology]. Moscow : Reflbuk [in Russian].

Piaget, J. (1959). The language and thought of the child (Marjorie and Ruth Cabain, Trans.). New York : Routledge \& Kegan Paul.

Pirozhenko, T.O. (1999). Movlenneve zrostannya doshkilnika [Speech development of a preschool child]. Kyiv : Grajlik [in Ukrainian].

Pirozhenko, T.O. (2002). Movlenneva geneza v osobistisnomu vimiri [Speech genesis in personal dimention]. Problemi zagalnoyi ta pedagogichnoyi psihologii - The problems of general and pedagogic psychology (Vol. IV, Ch. 7), (pp. 192-199) [in Ukrainian].

Pirozhenko, T.O. (2003). Psixichnij rozvitok ditini doshkilnogo viku: dosvid roboti suchasnogo doshkilnogo zakladu [Psychological development of a preschool age child: experience of work of a modern preschool establishment]. Zaporizhzhya : Lips ltd. [in Ukrainian].

Pirozhenko, T.A., \& Tishhenko, S.P. (1992). Nekotorye osobennosti geneza obraza «ya» doshkolnikov pri vozdejstvi na nix neblagopriyatnoj socio-ekologicheskoj obstanovki [Specifics of genesis of the image "I» of preschoolers by the nfluence of negative socio-ecological atmosphere]. Kyiv [in Russian].

Pirozhenko, T.O. (2010). Komunikativno-movlennevij rozvitok doshkilnika [Communicative-speech development of a preschooler]. Ternopil : Mandrivec [in Ukrainian].

Soroka, I.A. (2017). Fostering 21st century learning skills at English classes (pp. 201204). Kyiv : KPI named after Igor Sikorskyi, «Politexnika».

Tomasello, M. (2000). Do young children have adult syntactic competence? Cognition, 74(3), 209-253.

Tomasello, M. (2008). Origins of Human Communication. Cambridge, Massachusetts : MIT Press.

Vygotsky, L. (1986). Thought and language (Kozulin, Alex, Trans.). Cambridge, MA : The MIT Press.

\section{АНОТАЦІЯ}

У статті представлена характеристика комунікативно-мовленнєвого розвитку дитини в єдності поведінкових, пізнавальних, творчих якостей. здійснено інтеграційний підхід до оцінки стану особистісної активності та самореалізації дитини через генезис мови. В роботі аналізуються критеріальні оцінки, діагностична експертиза рівня мовного розвитку дитини з позиції комунікативного спрямування, авторська методика обстеження в єдності емоційно-вольових, 
когнітивних, творчих якостей мовлення. Проаналізовано базові підстави комунікативно-мовленнєвого розвитку дітей у взаємозв'язку складових характеристик конативного, когнітивно-лінгвістичного, особистісного рівнів, узагальнені вікові закономірності розвитку компетентності дитини у сфері мовної комунікації. Конативні досягнення молодшого дошкільника забезпечують формування таких особистісних якостей як комунікативна спрямованість до навколишнього світу, відкритість досвіду дорослих і однолітків, що, в свою чергу призводить до зростання когнітивної складності мовної поведінки дитини середнього дошкільного віку. Когнітивно-лінгвістичний рівень досягнень дитини пов'язаний із засвоєнням відносин "людина-ситуація» $i$ відносин "лінгвістична форма-значення». Мова стає об'єктом маніпулящії $і$ усвідомлення. Сфрормованість різних фрорм мовних висловлювань, адекватних ситуації i партнерському оточенню, забезпечує дитині реалізацію потреб спілкування, подальший розвиток і ускладнення ділових і пізнавальних форм взаємодії, розвиток способів і процесів мислення, творчість в мовному спілкуванні. Порівняльний аналіз психічної зрілості дітей дошкільного віку в експериментальних та контрольних групах дозволяє припустити, що розвиток основних комунікативних і мовних якостей у різні вікові періоди лягає в основу гармонійного розвитку особистості, оскільки воно виявляє потенційні здібності дитини.

Ключові слова: комунікативно-мовленнєвий розвиток, конативні, когнітивно-лінгвістичні, особистісні якості мови, мовна компетентність.

Пироженко Тамара, Сорока Ирина. Тенденции и динамика коммуникативно-речевого развития ребёнка дошкольного возраста

\section{АННОТАЦИЯ}

В статье представлена характеристика коммуникативно-речевого развития ребенка в единстве поведенческих, познавательных, творческих качеств. Описан интеграционный подход $к$ оценке состояния личностной активности и самореализации ребенка через генезис языка. В работе анализируются критериальные показатели, диагностическая экспертиза уровня речевого развития ребенка с позиции коммуникативного направления; представлена авторская методика диагностики в единстве эмоционально-волевых, когнитивных, творческих качеств речи детей дошкольного возраста. Проанализированы базовые основания коммуникативно-речевого развития детей во взаимосвязи составляющих характеристик конативного, когнитивно-лингвистического, личностного уровней, обобщенные возрастные закономерности развития компетентности 
Tendency and Dynamics of Communicative-Speech Development...

ребенка в сфере языковой коммуникации. Конативного достижения младшего дошкольника обеспечивают формирование таких личностных качеств как коммуникативная направленность к окружающему миру, открытость опыту взрослых и сверстников, что, в свою очередь приводит к росту когнитивной сложности речевого поведения ребенка среднего дошкольного возраста. Когнитивно-лингвистический уровень достижений ребенка связан с усвоением отношений «человек-ситуация» и отношений "лингвистическая форма-значение». Язык становится объектом манипуляции и осознания. Сформированность различных форм речевых высказываний, адекватных ситуации и партнерском окружению, обеспечивает ребенку реализацию потребностей общения, дальнейшее развитие и усложнение деловых и познавательных форм взаимодействия, развитие способов и прочессов мышления, творчество в речевом общении. Сравнительный анализ психической зрелости детей дошкольного возраста в экспериментальных и контрольных группах позволяет предположить, что развитие основных коммуникативных и языковых качеств в разные возрастные периоды ложится в основу гармоничного развития личности, поскольку оно обнаруживает потенциальные способности ребенка.

Ключевые слова: коммуникативно-речевое развитие, конативного, когнитивно-лингвистические, личностные качества языка, языковая компетентность. 